\title{
Examination of group cohesiveness levels and goal orientations of basketball players
}

\author{
Can Çavin Ötkan ${ }^{1 a}$, Gönül Tekkurşun Demir ${ }^{2}$, and AlperenHalıcı ${ }^{3}$ \\ ${ }^{1}$ Faculty of Sport Science, Gazi University/YüzüncüYıl University, 06000 Ankara, Turkey \\ ${ }^{2}$ Faculty of Sport Science, Gazi University, 06000 Ankara, Turkey
}

\begin{abstract}
This research intends to examine goal orientation and group cohesiveness levels of basketball players. 243 mature players who play in the leagues of Turkish Basketball Federation in 20162017 season participated the study. "Task and Ego Orientation in Sports" and "Group Cohesiveness" questionnaires are used in study. While frequency, arithmetic mean and standard deviation is used for the analysis of data, T-Test, One-Way Analysis of Variance (ANOVA) and Post-Hoc test statistics (Tukey HSD) are used for independent samples. Depending on the variables of gender and educational background of players, a significant difference is identified in sub-dimension of Task Attraction of Group and a low-level negatively significant difference is identified between Ego Orientation in terms of age and sportive age. Significant differences are identified between the Perception of Team Success and sub-dimensions of Social Integration of Group and Social Attraction of Group. No statistically significant difference can be found for the variable of time spent in team in terms of group cohesiveness and goal orientation.
\end{abstract}

Keywords: Group cohesiveness, goal orientations, motivation, basketball.

\section{Introduction}

There are some major facts to achieve the intended objectives in all team sports. Mental potentials of athletes as well as their physical and technical capacities are critical criteria. Particularly in terms of team sports, the levels of individuals to feel that they belong to the group and orientating themselves, as well as their attitudes

${ }^{a}$ Corresponding author: cancavitotkan@gazi.edu.tr 
towards the tasks undertaken in line with intended objectives are requisites of group $[12,17]$. In this context, group cohesiveness and task and ego orientation levels of individuals in the group play an important role in the future of organization.

Cohesiveness which represents the sum of factors and strengths providing group members to stay in group is also generally defined as the level of their attraction to each other and to group [5].

When cohesiveness is examined specific to team sports we see that it has two basic dimensions; task cohesiveness and social cohesiveness. Team cohesiveness describes the process where group members attach themselves to each other in order to achieve intended objectives and/or due to emotional interaction between them and sustain this state [4].

It is stated that the pleasure felt due to the long-time togetherness of team members, homogeneity of group, size of group, cooperation in group and successful performance is an important factor to constitute and develop cohesiveness in a sportive group [14].

In relation to goal oriented motivation in sports the concepts of group cohesiveness of team members, goal orientation with regard to task in behavioral sense and goal orientation in sense of ego intersect at many points [7].

It is observed that athletes who are used to goal orientation in sense of task attach more importance to team rapport and cooperation, development of skills, getting specialized in task and learning while athletes who are used to goal orientation in sense of ego take overcoming their competitors, being superior and focusing on result to forefront [18]. Task oriented athletes believe in the necessity of skill development and intense practice to make it possible. They are more inclined to use internal motivation to fight with resistance and obstacles they face on the road to success. Ego oriented athletes, on the other hand, are more inclined to follow the exact opposite road and exhibit unsporting behaviors to succeed when they face with a similar resistance [20].

When these facts are taken into consideration, it is thought that assessment of cohesiveness levels of groups and how relational are the ego-task orientations of individuals would be beneficial. This research intends to examine the said variables specific to basketball to the accompaniment of different demographic information.

\section{Method}

\subsection{Research model}

Out of general screening models, the relational screening model is used in this research to descriptively reveal the relation of group cohesiveness of basketball players with their task and ego orientations. Relational screening model is a research model which describes the extents of differences between two or more variables [13].

\subsection{Universe and sampling}

Universe of research is composed of mature players who play in the leagues of Turkish Basketball Federation in 2016-2017 season. Sample group is composed of 243 individuals, 152 of whom are males and 91 are females. 


\subsection{Data collection tools}

“Group Environment Questionnaire", a nine points Likert Questionnaire developed by Carron, Widmayer and Brawley [5] and adapted to Turkish by Öcel [17] is used to measure the group cohesiveness levels of basketball players. In Turkish version of the Questionnaire which is composed of 18 points and 4 sub-dimensions, Cronbach's Alpha Internal Consistency Coefficients are found as .59, .67, .50, .65 and .64 for "Dimension of Task Integration in Group", "Dimension of Social Integration in Group", "Dimension of Social Attraction in Group", "Dimension of Task Attraction in Group" and all of them together respectively. "Task and Ego Orientation in Sports Questionnaire", a five points Likert Questionnaire developed by Duda and Nichols and adapted for Turkish athletes by Toros [19] is used to determine task and ego orientations of athletes. There are 2 sub-dimensions of the 13-point Questionnaire to measure task oriented objectives and ego oriented objectives. Cronbach's Alpha Internal Consistency Coefficients in Turkish version of Questionnaire are found as .87, .85 and .86 for "task oriented objectives", "ego oriented objectives" and general reliability coefficient respectively.

\subsection{Analysis of data}

Data obtained from participants are statistically analyzed by using SPSS 23 package program. Before determining the statistical methods to be used, skewness and kurtosis values (normal distribution of data) are tested and Levene's test (equality of variances) is conducted. In this context, it is seen in research that Skewness and Kurtosis values of each independent variable range from +1 to -1 . If skewness coefficient is between the range of +1 and -1 , it is interpreted as there is no significant deviation from normal distribution of points (9). After testing the homogeneity of variances of normally distributed variables, these variables are tested via parametric test methods. Frequency, arithmetic mean and standard deviation are used to analyze data and T-Test, One-Way Analysis of Variance (ANOVA) and Post-Hoc test statistics (Tukey HSD) are used for independent samples.

\section{Findings}

This section includes findings obtained in line with various statistical processes applied to data given by participants and interpretations. 
Table 1. Independent group $t$ test results to determine whether or not there is differentiation according to gender variable

\begin{tabular}{|c|c|c|c|c|c|c|c|c|}
\hline \multirow{5}{*}{ } & & Cinsiyet & $\mathrm{N}$ & $\bar{x}$ & Ss & $\mathrm{df}$ & $\mathrm{t}$ & $\mathrm{p}$ \\
\hline & Task & Male & 152 & 30,6053 & 3,96868 & \multirow{2}{*}{241} & \multirow{2}{*}{1,375} & \multirow{2}{*}{,171 } \\
\hline & Orientation & Female & 91 & 29,8242 & 4,77399 & & & \\
\hline & \multirow{2}{*}{$\begin{array}{c}\text { Ego } \\
\text { Orientation }\end{array}$} & Male & 152 & 20,5855 & 5,77439 & \multirow{2}{*}{241} & \multirow{2}{*}{,741 } & \multirow{2}{*}{,459 } \\
\hline & & Female & 91 & 20,0440 & 5,04185 & & & \\
\hline \multirow{8}{*}{ 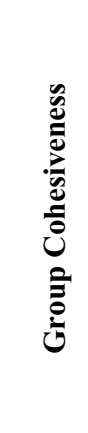 } & \multirow{2}{*}{$\begin{array}{c}\text { Social } \\
\text { Integration } \\
\text { of Group }\end{array}$} & Male & 152 & 24,7171 & 8,57180 & \multirow[b]{2}{*}{241} & \multirow[b]{2}{*}{1,472} & \multirow[b]{2}{*}{,142 } \\
\hline & & Female & 91 & 23,0879 & 7,96471 & & & \\
\hline & \multirow{2}{*}{$\begin{array}{c}\text { Task } \\
\text { Attraction } \\
\text { of Group }\end{array}$} & Male & 152 & 21,0789 & 7,08092 & \multirow{2}{*}{241} & \multirow{2}{*}{2,272} & \multirow{2}{*}{, $024 *$} \\
\hline & & Female & 91 & 19,0879 & 5,74195 & & & \\
\hline & \multirow{2}{*}{$\begin{array}{c}\text { Social } \\
\text { Attraction } \\
\text { of Group }\end{array}$} & Male & 152 & 23,2303 & 6,74264 & \multirow{2}{*}{241} & \multirow{2}{*}{,427 } & \multirow{2}{*}{,670 } \\
\hline & & Female & 91 & 22,8462 & 6,85229 & & & \\
\hline & \multirow{2}{*}{$\begin{array}{c}\text { Task } \\
\text { Integration } \\
\text { of Group }\end{array}$} & Male & 152 & 12,3750 & 4,11235 & \multirow[b]{2}{*}{241} & \multirow{2}{*}{,- 554} & \multirow{2}{*}{,580 } \\
\hline & & Female & 91 & 12,6703 & 3,85589 & & & \\
\hline
\end{tabular}

${ }^{*} \mathrm{p}<.05$

Whether there is a significant difference in level of group cohesiveness and goal orientation of participants in independent groups or not in terms of gender variable is examined via $t$-test in Table 1 . Accordingly, a significant difference is identified in dimension of Task Attraction of Group in terms of gender variable.

Table 2. Age variable correlation results according to group cohesiveness and goal orientation

\begin{tabular}{|c|c|c|c|c|c|}
\hline & $\mathrm{N}$ & $\bar{x}$ & ss & $\mathrm{r}$ & $\mathrm{p}$ \\
\hline Age Variable & \multirow{2}{*}{243} & 2,2181 & 1,07841 & \multirow{2}{*}{,- 034} & \multirow{2}{*}{, 593} \\
\hline Task Orientation & & 30,3128 & 4,29502 & & \\
\hline Age Variable & \multirow{2}{*}{243} & 2,2181 & 1,07841 & \multirow{2}{*}{,$- 210^{* *}$} & \multirow{2}{*}{, $001 *$} \\
\hline Ego Orientation & & 20,3827 & 5,50710 & & \\
\hline Age Variable & \multirow{2}{*}{243} & 2,2181 & 1,07841 & \multirow{2}{*}{,- 035} & \multirow{2}{*}{, 591} \\
\hline Social Integration of Group & & 24,1070 & 8,37036 & & \\
\hline Age Variable & \multirow{2}{*}{243} & 2,2181 & 1,07841 & \multirow{2}{*}{, 032} & \multirow{2}{*}{,616 } \\
\hline Task Attraction of Group & & 20,3333 & 6,66928 & & \\
\hline Age Variable & \multirow{2}{*}{243} & 2,2181 & 1,07841 & \multirow{2}{*}{,- 120} & \multirow{2}{*}{, 061} \\
\hline Social Attraction of Group & & 23,0864 & 6,77233 & & \\
\hline Age Variable & \multirow{2}{*}{243} & 2,2181 & 1,07841 & \multirow{2}{*}{,- 013} & \multirow{2}{*}{,839 } \\
\hline Task Integration of Group & & 12,4856 & 4,01274 & & \\
\hline
\end{tabular}


Table 2 shows the results of Pearson Moment Correlation Analysis performed to determine if there is a relation between participants' level of group cohesiveness and goal orientation and age variable or not. In this context, it is seen that there is a negative low-level significant difference between Ego Orientation of athletes and age variable.

Table 3. Sportive age variable correlation results according to group cohesiveness and goal orientation

\begin{tabular}{|c|c|c|c|c|c|}
\hline Değişken & $\mathrm{N}$ & $\bar{x}$ & ss & $\mathrm{r}$ & $\mathrm{P}$ \\
\hline $\begin{array}{c}\text { Sportive Age } \\
\text { Variable } \\
\end{array}$ & \multirow{2}{*}{243} & 2,6255 & ,87415 & \multirow{2}{*}{,- 036} & \multirow{2}{*}{,579 } \\
\hline Task Orientation & & 30,3128 & 4,29502 & & \\
\hline $\begin{array}{c}\text { Sportive Age } \\
\text { Variable }\end{array}$ & \multirow{2}{*}{243} & 2,6255 & ,87415 & \multirow{2}{*}{,$- 214^{* *}$} & \multirow{2}{*}{, $001 *$} \\
\hline Ego Orientation & & 20,3827 & 5,50710 & & \\
\hline $\begin{array}{c}\text { Sportive Age } \\
\text { Variable }\end{array}$ & \multirow{2}{*}{243} & 2,6255 & ,87415 & \multirow{2}{*}{,- 043} & \multirow{2}{*}{, 591} \\
\hline $\begin{array}{l}\text { Social Integration of } \\
\text { Group }\end{array}$ & & 24,1070 & 8,37036 & & \\
\hline $\begin{array}{c}\text { Sportive Age } \\
\text { Variable }\end{array}$ & \multirow{2}{*}{243} & 2,6255 & 87415 & \multirow{2}{*}{, 034} & \multirow{2}{*}{, 595} \\
\hline $\begin{array}{l}\text { Task Attraction of } \\
\text { Group }\end{array}$ & & 20,3333 & 6,66928 & & \\
\hline $\begin{array}{c}\text { Sportive Age } \\
\text { Variable }\end{array}$ & \multirow{2}{*}{243} & 2,6255 & ,87415 & \multirow{2}{*}{,- 026} & \multirow{2}{*}{,688 } \\
\hline $\begin{array}{l}\text { Social Attraction of } \\
\text { Group }\end{array}$ & & 23,0864 & 6,77233 & & \\
\hline $\begin{array}{c}\text { Sportive Age } \\
\text { Variable }\end{array}$ & \multirow{2}{*}{243} & 2,6255 & ,87415 & \multirow{2}{*}{,- 005} & \multirow{2}{*}{,939 } \\
\hline $\begin{array}{l}\text { Task Integration of } \\
\text { Group }\end{array}$ & & 12,4856 & 4,01274 & & \\
\hline
\end{tabular}

Table 3 shows the results of Pearson Moment Correlation Analysis performed to determine if there is a relation between participants' level of group cohesiveness and goal orientation and sportive age variable or not. In this context, it is seen that there is a negative low-level significant difference between Ego Orientation of athletes and sportive age variable as in the case of age variable. 
Table 4. Anova results according to educational status

\begin{tabular}{|c|c|c|c|c|c|c|c|c|c|}
\hline & & $\mathrm{N}$ & $\bar{x}$ & $\begin{array}{c}\text { Varianc } \\
\text { e } \\
\text { Source }\end{array}$ & $\begin{array}{l}\text { Sum of } \\
\text { Squares }\end{array}$ & $\begin{array}{l}\text { Avg. of } \\
\text { Squares }\end{array}$ & $\mathrm{F}$ & $\mathrm{p}$ & $\begin{array}{l}\text { Sig. } \\
\text { Dif. }\end{array}$ \\
\hline \multirow{3}{*}{ 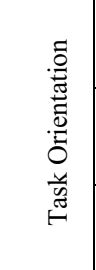 } & $\begin{array}{l}\text { High } \\
\text { School }\end{array}$ & 12 & $\begin{array}{r}28,666 \\
7\end{array}$ & \multirow{2}{*}{$\begin{array}{c}\text { Inter } \\
\text { Groups }\end{array}$} & \multirow{3}{*}{$\begin{array}{l}34,497 \\
4429,733\end{array}$} & \multirow{3}{*}{$\begin{array}{l}17,249 \\
18,45 \\
7\end{array}$} & \multirow{3}{*}{,935 } & \multirow{3}{*}{,394 } & \multirow{3}{*}{-} \\
\hline & $\begin{array}{l}\text { Undergradu } \\
\text { ate }\end{array}$ & $\begin{array}{r}21 \\
0\end{array}$ & $\begin{array}{r}30,409 \\
5\end{array}$ & & & & & & \\
\hline & $\begin{array}{l}\text { Postgradua } \\
\text { te }\end{array}$ & 21 & $\begin{array}{r}30,285 \\
7\end{array}$ & $\begin{array}{c}\text { InGrou } \\
\mathrm{p}\end{array}$ & & & & & \\
\hline \multirow{3}{*}{ 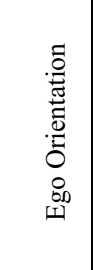 } & $\begin{array}{l}\text { High } \\
\text { School }\end{array}$ & 12 & $\begin{array}{r}18,916 \\
7\end{array}$ & \multirow{2}{*}{$\begin{array}{c}\text { Inter } \\
\text { Groups }\end{array}$} & \multirow{3}{*}{$\begin{array}{l}28,257 \\
7311,15 \\
0\end{array}$} & \multirow{3}{*}{$\begin{array}{l}14,129 \\
30,46 \\
3\end{array}$} & \multirow{3}{*}{,464 } & \multirow{3}{*}{,629 } & \multirow{3}{*}{-} \\
\hline & $\begin{array}{l}\text { Undergradu } \\
\text { ate }\end{array}$ & $\begin{array}{r}21 \\
0\end{array}$ & $\begin{array}{r}20,481 \\
0\end{array}$ & & & & & & \\
\hline & $\begin{array}{l}\text { Postgradua } \\
\text { te }\end{array}$ & 21 & $\begin{array}{r}20,238 \\
1\end{array}$ & $\begin{array}{c}\text { InGrou } \\
\mathrm{p}\end{array}$ & & & & & \\
\hline \multirow{3}{*}{ 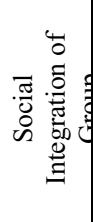 } & $\begin{array}{l}\text { High } \\
\text { School }\end{array}$ & 12 & $\begin{array}{r}22,166 \\
7\end{array}$ & \multirow{2}{*}{$\begin{array}{c}\text { Inter } \\
\text { Groups }\end{array}$} & \multirow[t]{3}{*}{96,6901} & \multirow{3}{*}{$\begin{array}{l}48,34 \\
5 \\
\\
70,24 \\
4\end{array}$} & \multirow{3}{*}{,688 } & \multirow{3}{*}{, 503} & \multirow{3}{*}{ - } \\
\hline & $\begin{array}{l}\text { Undergradu } \\
\text { ate }\end{array}$ & $\begin{array}{r}21 \\
0\end{array}$ & $\begin{array}{r}24,061 \\
9\end{array}$ & & & & & & \\
\hline & $\begin{array}{l}\text { Postgradua } \\
\text { te }\end{array}$ & 21 & $\begin{array}{r}25,666 \\
7 \\
\end{array}$ & $\begin{array}{c}\text { InGrou } \\
\mathrm{p}\end{array}$ & & & & & \\
\hline \multirow{3}{*}{ 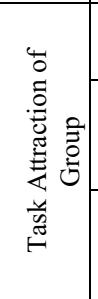 } & $\begin{array}{l}\text { High } \\
\text { School }^{\text {a }}\end{array}$ & 12 & $\begin{array}{r}18,833 \\
3 \\
\end{array}$ & \multirow{2}{*}{$\begin{array}{c}\text { Inter } \\
\text { Groups }\end{array}$} & \multirow{3}{*}{$\begin{array}{l}419,095 \\
10344,90 \\
5\end{array}$} & \multirow{3}{*}{$\begin{array}{l}209,54 \\
8 \\
43,10 \\
4\end{array}$} & \multirow{3}{*}{$\begin{array}{r}4,86 \\
1\end{array}$} & \multirow{3}{*}{$\begin{array}{r}, 009 \\
*\end{array}$} & \multirow{3}{*}{$\begin{array}{c}c>b> \\
a\end{array}$} \\
\hline & $\begin{array}{l}\text { Undergradu } \\
\text { ate }^{\mathrm{b}}\end{array}$ & $\begin{array}{r}21 \\
0\end{array}$ & $\begin{array}{r}20,000 \\
0\end{array}$ & & & & & & \\
\hline & $\begin{array}{l}\text { Postgradua } \\
\mathrm{te}^{\mathrm{c}}\end{array}$ & 21 & $\begin{array}{r}24,523 \\
8\end{array}$ & $\begin{array}{c}\text { InGrou } \\
\mathrm{p}\end{array}$ & & & & & \\
\hline \multirow{3}{*}{ 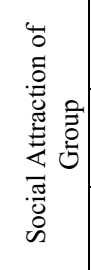 } & $\begin{array}{l}\text { High } \\
\text { School }\end{array}$ & 12 & $\begin{array}{r}23,666 \\
7\end{array}$ & \multirow{2}{*}{$\begin{array}{c}\text { Inter } \\
\text { Groups }\end{array}$} & \multirow{3}{*}{$\begin{array}{l}5,466 \\
11093,71 \\
9\end{array}$} & \multirow{3}{*}{$\begin{array}{l}2,733 \\
46,22 \\
4\end{array}$} & \multirow{3}{*}{,059 } & \multirow{3}{*}{,943 } & \multirow{3}{*}{-} \\
\hline & $\begin{array}{l}\text { Undergradu } \\
\text { ate }\end{array}$ & $\begin{array}{r}21 \\
0\end{array}$ & $\begin{array}{r}23,033 \\
3\end{array}$ & & & & & & \\
\hline & $\begin{array}{l}\text { Postgradua } \\
\text { te }\end{array}$ & 21 & $\begin{array}{r}23,285 \\
7\end{array}$ & $\begin{array}{c}\text { InGrou } \\
\mathrm{p}\end{array}$ & & & & & \\
\hline $\begin{array}{l}4 \\
0 \\
0\end{array}$ & $\begin{array}{l}\text { High } \\
\text { School }\end{array}$ & 12 & $\begin{array}{r}14,750 \\
0\end{array}$ & Inter & & & & & \\
\hline 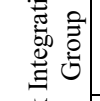 & $\begin{array}{l}\text { Undergradu } \\
\text { ate }\end{array}$ & $\begin{array}{r}21 \\
0\end{array}$ & $\begin{array}{r}12,428 \\
6\end{array}$ & Groups & $\begin{array}{l}3823,48 \\
8\end{array}$ & 15,93 & $\begin{array}{r}1,38 \\
7\end{array}$ & ,252 & - \\
\hline$\stackrel{\frac{\pi}{\tilde{a}}}{=}$ & $\begin{array}{l}\text { Postgradua } \\
\text { te }\end{array}$ & 21 & $\begin{array}{r}11,761 \\
9\end{array}$ & $\begin{array}{c}\text { InGrou } \\
\mathrm{p}\end{array}$ & & 1 & & & \\
\hline
\end{tabular}


As seen from Table 4, one-way variance analysis applied to points in "Group Cohesiveness Questionnaire" and "Task and Ego Orientation in Sports Questionnaire" in terms of educational backgrounds of participants revealed a significant difference in sub-dimension of Task Attraction of Group ( $\mathrm{F}=4,861$; $\mathrm{p}=, 009)$ under "Group Cohesiveness Questionnaire". In order to determine the source of the significant difference appears between groups as a result of this analysis, Post-Hoc test statistics are applied (Tukey HSD). Groups which the score (point) difference is in favor of are stated in table. Accordingly, it is identified that participants with postgraduate education received higher points than the ones with undergraduate and high school education in sub-dimension of Task Attraction of Group and showed a significant difference.

Table 5. Anova results according to number of seasons in the team

\begin{tabular}{|c|c|c|c|c|c|c|c|c|c|}
\hline & & $\mathrm{N}$ & $\bar{x}$ & $\begin{array}{l}\text { Varianc } \\
\text { e Source }\end{array}$ & $\begin{array}{l}\text { Sum of } \\
\text { Squares }\end{array}$ & $\begin{array}{l}\text { Avg. of } \\
\text { Squares }\end{array}$ & $\mathrm{F}$ & $\mathrm{p}$ & $\begin{array}{l}\text { Sig } \\
\text { Dif }\end{array}$ \\
\hline \multirow{3}{*}{ 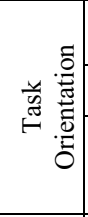 } & $\begin{array}{l}1 \text { and } \\
\text { Under }\end{array}$ & 131 & 29,7786 & \multirow{3}{*}{$\begin{array}{c}\text { Inter } \\
\text { Groups }\end{array}$} & \multirow{3}{*}{$\begin{array}{r}82,759 \\
4381,472\end{array}$} & \multirow{3}{*}{$\begin{array}{l}41,379 \\
18,256\end{array}$} & \multirow{3}{*}{2,267} & \multirow{3}{*}{,106 } & \multirow{3}{*}{-} \\
\hline & 2 & 61 & 31,0492 & & & & & & \\
\hline & $\begin{array}{l}3 \\
\text { andO } \\
\text { ver } \\
\end{array}$ & 51 & 30,8039 & & & & & & \\
\hline \multirow{3}{*}{ 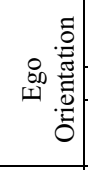 } & $\begin{array}{l}1 \text { and } \\
\text { Under }\end{array}$ & 131 & 19,7252 & \multirow{3}{*}{$\begin{array}{c}\text { Inter } \\
\text { Groups } \\
\text { InGroup }\end{array}$} & \multirow{3}{*}{$\begin{array}{r}123,877 \\
7215,531\end{array}$} & \multirow{3}{*}{$\begin{array}{l}61,938 \\
30,065\end{array}$} & \multirow{3}{*}{2,060} & \multirow{3}{*}{, 130} & \multirow{3}{*}{-} \\
\hline & 2 & 61 & 21,0656 & & & & & & \\
\hline & $\begin{array}{l}3 \text { and } \\
\text { Over }\end{array}$ & 51 & 21,2549 & & & & & & \\
\hline \multirow{3}{*}{ 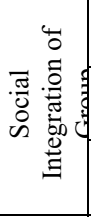 } & $\begin{array}{l}1 \text { and } \\
\text { Under }\end{array}$ & 131 & 23,3817 & \multirow{3}{*}{$\begin{array}{c}\text { Inter } \\
\text { Groups }\end{array}$} & \multirow{3}{*}{$\begin{array}{r}234,991 \\
16720,22 \\
8\end{array}$} & \multirow{3}{*}{$\begin{array}{r}117,49 \\
5 \\
69,668\end{array}$} & \multirow{3}{*}{1,687} & \multirow{3}{*}{, 187 } & \multirow{3}{*}{-} \\
\hline & 2 & 61 & 25,7541 & & & & & & \\
\hline & $\begin{array}{l}3 \text { and } \\
\text { Over }\end{array}$ & 51 & 24,0000 & & & & & & \\
\hline \multirow{3}{*}{ 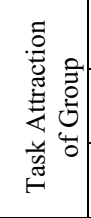 } & $\begin{array}{l}1 \text { and } \\
\text { Under }\end{array}$ & 131 & 20,1145 & \multirow{3}{*}{$\begin{array}{c}\text { Inter } \\
\text { Groups }\end{array}$} & \multirow{3}{*}{$\begin{array}{r}130,359 \\
10633,64 \\
1\end{array}$} & \multirow{3}{*}{$\begin{array}{l}65,179 \\
44,307\end{array}$} & \multirow{3}{*}{1,471} & \multirow{3}{*}{,232 } & \multirow{3}{*}{-} \\
\hline & 2 & 61 & 19,6557 & & & & & & \\
\hline & $\begin{array}{l}3 \text { and } \\
\text { Over }\end{array}$ & 51 & 21,7059 & & & & & & \\
\hline \multirow{3}{*}{ 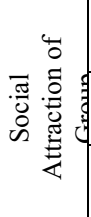 } & $\begin{array}{l}1 \text { and } \\
\text { Under }\end{array}$ & 131 & 22,5649 & \multirow{3}{*}{$\begin{array}{c}\text { Inter } \\
\text { Groups } \\
\text { In } \\
\text { Group }\end{array}$} & \multirow{3}{*}{$\begin{array}{r}158,597 \\
10940,58 \\
8\end{array}$} & \multirow{3}{*}{$\begin{array}{l}79,299 \\
45,586\end{array}$} & \multirow{3}{*}{1,740} & \multirow{3}{*}{, 178} & \multirow{3}{*}{-} \\
\hline & 2 & 61 & 24,4754 & & & & & & \\
\hline & $\begin{array}{l}3 \text { and } \\
\text { Over }\end{array}$ & 51 & 22,7647 & & & & & & \\
\hline $\begin{array}{l}4 \\
0 \\
0\end{array}$ & $\begin{array}{l}1 \text { and } \\
\text { Under }\end{array}$ & 131 & 12,3282 & $\begin{array}{l}\text { Inter } \\
\text { Grouns }\end{array}$ & & & & & \\
\hline 崖 & 2 & 61 & 13,2295 & & 49,027 & 24,514 & 1,529 & ,219 & - \\
\hline$\stackrel{\Xi}{\Xi}$ & $\begin{array}{l}3 \text { and } \\
\text { Over }\end{array}$ & 51 & 12,0000 & $\begin{array}{c}\text { In } \\
\text { Group }\end{array}$ & & & & & \\
\hline
\end{tabular}

As seen from Table 5, no significant difference is identified in one-way variance analysis applied to "Group Cohesiveness Questionnaire" and "Goal and Ego 
Orientation in Sports Questionnaire" points received by participants in terms of the number of seasons that participants have been part of their teams.

Table 6. Anova results according toteam's perception of success

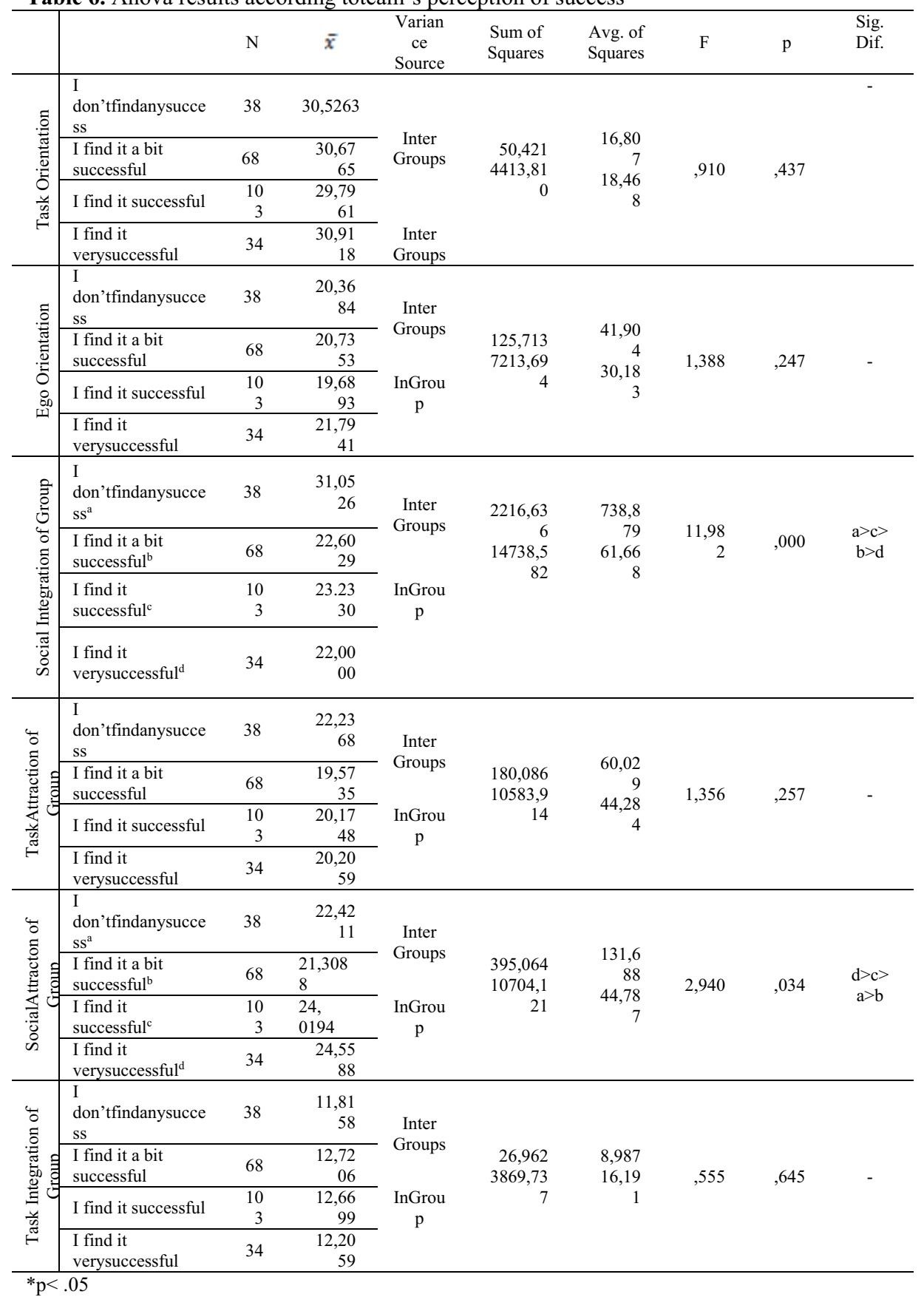


Table 6 shows the results of one-way variance analysis applied to "Group Cohesiveness Questionnaire" and Task and Ego Orientation in Sports Questionnaire" points received by participants in terms of team's perception of success. Significant differences are identified in sub-dimension of Social Integration of Group $(\mathrm{F}=2.940 ; \mathrm{p}=.034)$ and sub-dimension of Social Attraction of Group $(\mathrm{F}=11.982 ; \mathrm{p}=.000)$ under "Group Cohesiveness Questionnaire". Groups which the score (point) difference is in favor of are stated in table.

\section{Discussion and conclusion}

It was intended to determine group cohesiveness goal orientation levels of mature basketball players who play in the leagues of Turkish Basketball Federation in 20162017 season in the light of different demographic information in this research. At the end of the analyses conducted accordingly, data obtained from "Group Cohesiveness Questionnaire" and "Task and Ego Orientation in Sports Questionnaire" are examined in terms of gender variable. Eys, Evans, Ohlert, Wolf, Martin \& Van Bussel [8] aimed to examine cohesiveness of male and female athletes and obtained data from coaches with different demographic characteristics by using semistructured interview method. The said study suggests that cohesiveness level in teams composed of female athletes is lower because female athletes perceive everything more personally in comparison with male athletes. In this research, on the other hand, a significant difference in favor of male athletes is identified only in sub-dimension of Task Attraction of Group under "Group Cohesiveness Questionnaire". Haddera [10]; Gammage, Carron and Estabrooks [9]; Carron, Eys, Bray [4] could not find any difference which would be regarded significant between gender variable and group cohesiveness and Zakaria, Yasim and Taff [23] concluded in their study that group cohesiveness of male individuals is statistically more significant than female individuals. No significant difference is identified between gender variable and sub-dimensions of "Task and Ego Orientation in Sports Questionnaire". Altıntaş [1] identified a significant difference in favor of female athletes with regard to Task Orientation and Ego Orientation in his study on athletes from different branches. However White and Duda [22]; Duda [6]; Li, Harmer and Acock [16] concluded in their studies that there is a significant difference between gender and Ego Orientation in favor of males. On the other hand, Hanrahan and Cerin [11] and Duda [6] revealed in their studies that there is a significant difference with regard to Task Orientation sub-dimension in favor of females.

As a result of Pearson Moment Correlation analysis conducted to see whether there is a significant difference between group cohesiveness levels of participants and their goal orientation and age variable or not, it is observed that there is a lowlevel and negative significant relation between Ego Orientation of athletes and age variable. Same findings are reached with regard to sportive age variable and a lowlevel and negative significant relation is identified between sportive age and Ego Orientation. Even if this is a finding in parallel with the perception that athletes grow mature in sportive sense in line with aging and gaining experience and elude their egos and thus behave in a more task-oriented way, Lameiras, Almeida and Garcia-Mas [15] reached a contrariwise conclusion in their study conducted on male athletes and identified a low-level and negative relation between age variable and Task Orientation.

Üngür [21] examined goal orientations of participants in terms of age and 
sportive experience variables while Altıntaş [1] examined the same thing only in terms of sportive experience variable but could not find a significant relation. Haddera [10] examined the relation between age and sportive experience of participants with their group cohesiveness and identified a low-level and negative significant difference between the said variables and Task Attraction of Group.

Data obtained from participants are examined in terms of educational background variable and a significant difference is identified in sub-dimension of Task Attraction of Group. In this context, the points received from sub-dimension of Task Attraction of Group got higher in parallel with the increase in level of education. No statistically significant data could be obtained between educational background variable and none of the sub-dimensions of "Task and Ego Orientation in Sports Questionnaire" and in parallel with this finding, Üngür [21] also couldn't identify a significant relation between level of education and Goal Orientation in his study including amateur and professional football players.

When the variable of number of seasons in the same team is analyzed, no statistically significant data could be obtained both in sub-dimensions of "Group Cohesiveness Questionnaire" and "Task and Ego Orientation in Sports Questionnaire". A factor hindering the emergence of a significant difference between the group cohesiveness levels of participants might be the stability of individuals in their group rather than the number of seasons they had in the team.

When the findings regarding perception of team success are examined, significant differences are identified in sub-dimensions of Social Integration of Group and Social Attraction of Group. In this context, the participants who find their team very successful got highest points in Social Attraction of Group subdimension. In parallel with this finding, Carron, Colman, Wheeler and Stevens [3] revealed that performance of team and Social Attraction of Group are directly associated with each other in their meta-analysis regarding the relation between cohesiveness and performance of team. Öcel [17] identified a significant relation between perception of success and social attraction of group in his study. Participants who don't deem their team successful got highest points in Social Integration of Group sub-dimension. This could be assessed as the result of the desire of team members who fail on the field to be freed from the feeling of unsuccessfulness by socially integrating with each other. No finding is obtained regarding the impact of goal orientation on perception of success.

Fundamental characteristics of team members are directly related with performance and success in team sports. Goal orientations and cohesiveness levels of the group composed of athletes are two of these characteristics. In this study, it was intended to examine the said factors in light of different demographic information and identify their extent of impact on the success of teams. Physical capacities of athletes as well as their mental qualities are regarded as important parameters today. Therefore, this research intends to contribute to awareness of sport psychology by executives and trainers who form, design and program the teams and also contribute the future studies on this topic and literature via its findings. 


\section{References}

1. Altıntaş A. Comparison of Goal Orientations, Motivational Climates and Perceived Physical Competences of Athletes in Terms of Gender and Level of Experience. Postgraduate Thesis, Ankara University. (2010).

2. Büyüköztürk Ş. Data Analysis Handbook for Social Sciences. Ankara: PegemaYayıncilık. (2005)

3. Carron A. V., Colman M. M., Wheeler J., ve Stevens, D. Cohesion and performance in sport: A meta analysis. Journal of Sport and Exercise Psychology, 24 (2), 168-188. (2002).

4. Carron A. V., Eys M., ve Bray, S. Team Cohesion and Team Success in $\begin{array}{lllll}\text { Sport. Journal Of Sports Sciences, } 20 & \text { (2), 119-126. (2002). }\end{array}$ doi:10.1080/026404102317200828

5. Carron A.V., Widmeyer W. ve Brawley L. The Development of an Instrument to Assess Cohesion in Sport Teams: The Group Environment Questionnaire. Journal of Sport Psychology, 7, 244-266. (1985). doi: http://dx.doi.org/10.1123/jsp.7.3.244.

6. Duda, J. L. Relationship Between Task and Ego Orientation and the Perceived Purpose of Sport Among High School Athletes. Journal Of Sport \& Exercise Psychology, 11(3), 318-335. (1989).

7. Duda, J. L., \& White, S. A. Goal Orientations and Beliefs About the Causes of Sport Success Among Elite Skiers. Sport Psychologist, 6 (4), 334-343. (1992). doi: $10.1123 /$ tsp.6.4.334

8. Eys, M., Evans, M. B., Martin, L. J., Ohlert, J., Wolf, S. A., Van Bussel, M., ve Steins, C. Cohesion And Performance For Female And Male Sport Teams. The Sport Psychologist, 29(2), 97-109. (2015).

9. Gammage, K. L., Carron, A. V., \&Estabrooks, P. A. Team cohesion and individual productivity: The influence of the norm for productivity and the identifiability of individual effort. Small Group Research, 32(1), 3-18. (2001).

10. Haddera, T. A. Assessing the Relationships between Competitive Trait Anxiety, Self-Efficacy and Task Cohesion in Male and Female University Team Sports. CLEAR International Journal Of Research In Management, Sciences \& Technology, 5(10), 1-11. (2015).

11. Hanrahan, S. veCerin, E. Gender, level of participation, and type of sport: Differences in achievement goal orientation and attributional style. Journal Of Science And Medicine In Sport, 12(4), 508-512. (2009). doi:10.1016/j.jsams.2008.01.005

12. Howell, W. C., \&Dipboye, R. L. Essentials of Industrial and Organizational Psychology. Chicago: The Dorsey Pr., c1896. (1986).

13. Karasar N. Scientific Research Method: Theories, Principles, Techniques. (23rd Edition) Ankara: Nobel. (2012).

14. Kocaekşi, S. Identification of Relation of Group Cohesiveness and Affecting Variables with Success in Successful and Unsuccessful Handball Teams. Postgraduate Thesis, HacettepeUniversity. (2005).

15. Lameiras J., Almeida P. L. ve Garcia-Mas A. Relationships Between Cooperation And Goal Orientation Among Male Professional And SemiProfessional Team Athletes. Perceptual \& Motor Skills: Motor Skills \& Ergonomics, 119 (3), 851-860. (2014). 
16. Li, F., Harmer, P., \&Acock, A. The Task And Ego Orientation İn Sport Questionnaire: Construct Equivalence And Mean Differences Across Gender. Research Quarterly For Exercise And Sport, 67(2), 228-238. (1996)

17. Öcel H. Relations of Collective Competence-Self-Efficacy and Cohesiveness with Perception and Expectations of Success. Postgraduate Thesis,Hacettepe University. (2002).

18. Sari İ., Ilic J. veLjubojevic M. The Comparison of Task and Ego Orientation and General Self-Esteem of Turkish and Montenegrın Young Basketball Players. Kinesiology : International Journal of Fundamental and Applied Kinesiology, 45 (2), 203-212. (2013). http://hrcak.srce.hr/112756

19. Toros T. Reliability and Validity of "Task and Ego Orientation in Sport Questionnaire -TEOSQ-" For Turkish Athletes. Hacettepe Journal of Sport Sciences, 15 (3), 155-166. (2004).

20. Toros T., Akyüz U., Bayansalduz M. ve Soyer F. Examining the relationship between task-and ego-oriented goals and life satisfaction (A study of people doing mountaineering sports). Journal of Human Sciences, 7 (2), 1039-1050. (2010).

21. Üngür G. Relation between Goal Orientations and Perceived Motivational Climate of Amateur and Professional Football Players. Postgraduate Thesis, Ege University. (2009).

22. White, S. A. ve Duda, J. L. The relationship of gender, level of sport involvement, and participation motivation to task and ego orientation. International Journal of Sport Psychology, 25 (1), 4-18. (1994).

23. Zakaria, J., Yasim, M. M., \& Taff, M. M. The Impact of Adventure Based Activity at Malaysian National Service Training Programme on Team Cohesion: A Demographic Analysis. International Journal Of Sport Management, Recreation \& Tourism, 10, 64-79. (2012). 